\title{
Antioxidant Capacity, Mineral Content and Sensory Properties of Gluten-Free Rice and Buckwheat Cookies
}

\author{
Marijana Sakač*, Mladenka Pestorić, Aleksandra Mišan, Nataša Nedeljković, \\ Dubravka Jambrec, Pavle Jovanov, Vojislav Banjac, Aleksandra Torbica, \\ Miroslav Hadnađev and Anamarija Mandić
}

Institute of Food Technology, University of Novi Sad, Bulevar cara Lazara 1, RS-21000 Novi Sad, Serbia

Received: March 7, 2014

Accepted: December 9, 2014

\begin{abstract}
Summary
Light buckwheat flour was used to substitute rice flour at the level of 10, 20 and $30 \%$ to produce gluten-free cookies. The substitution of gluten-free cookie formulation with light buckwheat flour contributed to the significantly higher mineral content, especially magnesium, potassium, iron and copper, in comparison with the control rice cookies $(\mathrm{p}<0.05)$. Gluten-free cookies made with rice flour and buckwheat flour exhibited significantly higher total phenolic and rutin content, scavenging activity against 1,1-diphenyl-2-picrylhydrazyl radicals ( $\left.\mathrm{DPPH} \mathrm{H}^{*}\right)$, antioxidant activity and reducing power than the control cookies $(\mathrm{p}<0.05)$. Comparing all evaluated sensory properties, cookies containing $20 \%$ of light buckwheat flour had the most acceptable sensory properties. The obtained results of principal component analysis showed that the cookies with 20 and $30 \%$ buckwheat flour had better antioxidant and sensory properties in comparison with other two cookie samples.
\end{abstract}

Key words: gluten-free cookies, minerals, antioxidant activity, sensory properties, rice flour, buckwheat flour

\section{Introduction}

Coeliac disease is one of the most common chronic autoimmune disorders. It is related to the intolerance of proteins of gluten complex present in many common cereals such as wheat, rye, barley and oat. The symptoms of coeliac disease can only be avoided by adhering to a strict lifelong gluten-free diet.

A number of studies have indicated that the gluten-free diet is unbalanced in carbohydrates, proteins and fat and deficient in certain essential nutrients (1). Due to the limitation of some nutrients, the fortification of basic gluten-free formulations is recommended to develop value-added products. For instance, pseudocereal flour such as buckwheat has been utilized to produce gluten-free bread $(2-4)$ and pasta (5).

Cookies are widely consumed bakery products due to their long shelf life and strong consumer preference.
Although the structure-forming ability of gluten influences the rheological properties of dough and affects overall appearance of bakery products, the development of a gluten network in biscuit and cookie dough is minimal and undesirable (6). Therefore, the efforts in gluten-free cookie production are more frequently related to the fortification of gluten-free formulations to achieve better nutritional profile of biscuits and cookies with acceptable sensory properties. There are several papers on the enrichment of gluten-free biscuits and cookies $(7,8)$.

Rice and buckwheat flour types are recommended as the safe ingredients for coeliac patients since they possess no gluten and can be used in the production of bread (9) and cookies (8). Rice flour is known as the most suitable component for gluten-free formulations due to its mild taste, colourlessness, hypoallergenic properties and easily digestible carbohydrates (10). Buckwheat flour is charac- 
terized as a gluten-free ingredient containing well-balanced amino acids and is rich in polyphenols $(11,12)$. The dominant polyphenolic compound in buckwheat flour is rutin (13), shown to be a potent antioxidant (14). Buckwheat flour is abundant in minerals, especially magnesium and iron, which are lacking in gluten-free products $(2-4)$.

Schönlechner et al. (15) incorporated pseudocereal flour (amaranth, quinoa and buckwheat) in gluten-free biscuit formulations. Cookies based on rice and light buckwheat flour were initially characterized by Torbica et al. (8) from the aspect of their physicochemical and sensory characteristics and compared to the control which was based on wheat flour. According to the authors, the best quality of gluten-free rice cookies was achieved when they were enriched with $20 \%$ of light buckwheat flour.

Published papers in the available literature present results mainly focused on physicochemical or sensory characteristics of gluten-free cookies without any functional analysis such as antioxidant activity. Therefore, the objective of this paper is to investigate the antioxidant capacity, mineral content and sensory properties of the cookies made from rice and light buckwheat flour in three different ratios and to compare them with the control sample made from rice flour. In addition, principal component analysis was used to study and visualize the correlation among all tested properties of gluten-free cookies.

\section{Materials and Methods}

\section{Materials}

Rice flour (in \%: moisture 11.67, protein $(\mathrm{N} \times 5.7) 7.96$, fat 0.27 , ash 0.25 , reducing sugars 1.37 , starch 88.58 , and total dietary fibre 1.90) and light buckwheat flour (in \%: moisture 11.24, protein $(\mathrm{N} \times 5.7) 8.68$, fat 1.47 , ash 1.08 , reducing sugars 1.77, starch 85.38 , and total dietary fibre 5.20) were obtained from Hemija Komerc, Novi Sad, Serbia. Vegetable fat originating from refined palm and sunflower oil was obtained from Puratos NV, Groot-Bijgaarden, Belgium. Sodium hydrogen carbonate $(\geq 99.5 \%$, p.a) was purchased from Carl Roth $\mathrm{GmbH}$, Karlsruhe, Germany, carboxymethyl cellulose sodium salt from Alfa Aesar GmbH, Karlsruhe, Germany, diacetyl tartaric acid esters of monoglycerides (Pantex DW90) from InCoPa $\mathrm{GmbH}$, Munich, Germany, while the other ingredients (salt, sugar and honey) were purchased at the local market.

\section{Preparation of cookies}

The formulation of gluten-free cookies with rice and buckwheat flour was made according to Torbica et al. (8). Mixtures of the two types of flour were prepared, with the ratio of rice to buckwheat flour of 90:10, 80:20, and 70:30. Rice flour was used for the preparation of control cookies. Dough mixing, processing and baking were performed on laboratory-scale equipment. The ingredients were weighed as follows (in g): flour (rice flour 300 for the control cookies or rice flour and light buckwheat flour, respectively: 270 and 30 for the cookies with $10 \%$ flour substitution, 240 and 60 for the cookies with $20 \%$ flour substitution, and 210 and 90 for the cookies with $30 \%$ flour substitution), deionized water 75 , vegetable fat 85 , granulated sugar 70, honey $45, \mathrm{NaHCO}_{3}$ 9, diacetyl tartaric acid ester of monoglycerides 9, carboxymethyl cellulose 4.5, and salt 2.1.

Rice flour or rice/buckwheat flour mixtures were transferred into Farinograph mixing bowl (Brabender $\mathrm{GmbH}$, Duisburg, Germany), which was previously tempered at $30^{\circ} \mathrm{C}$. Afterwards, the rest of the dry ingredients and vegetable fat were added and mixed for $2 \mathrm{~min}$. Finally, $45 \mathrm{~g}$ of honey which was previously dissolved in deionized water was poured into the mixer bowl and the dough mass was mixed for $25 \mathrm{~min}$ at $30^{\circ} \mathrm{C}$. The obtained cookie dough was left to rest at $8{ }^{\circ} \mathrm{C}$ for $24 \mathrm{~h}$ in order to allow the hydration of the added carboxymethyl cellulose. After the resting period, the dough was tempered at ambient temperature for $30 \mathrm{~min}$ and then sheeted to a thickness of $4 \mathrm{~mm}$ using a pilot scale dough sheeter (Mignon, Mestrino, Italy). The dough was cut using a stainless mould $(60 \mathrm{~mm} \times 55 \mathrm{~mm})$ and finally baked at $170{ }^{\circ} \mathrm{C}$ for $12 \mathrm{~min}$ in a laboratory oven (MIWE gusto ${ }^{\circledR}$, MIWE Michael Wenz GmbH, Arnstein, Germany). The obtained cookies were cooled for $2 \mathrm{~h}$ at ambient temperature and packed in sealed polypropylene bags.

\section{Proximate composition and mineral content}

Proximate composition of cookies including protein (Official Method No. 950.36), fat (Official Method No. 935.38), reducing sugar (Official Method No. 975.14), total dietary fibre (Official Method No. 958.29), ash (Official Method No. 930.22) and moisture contents (Official Method No. 926.5) were determined by AOAC standard methods of analysis (16). Starch content was determined by hydrochloric acid dissolution according to the ICC Standard No. 123/1 (17).

Mineral content $(\mathrm{Mg}, \mathrm{K}, \mathrm{Zn}, \mathrm{Fe}, \mathrm{Mn}$ and $\mathrm{Cu})$ of cookies was determined using a Varian Spectra AA 10 (Varian Techtron Pty Limited, Mulgrave, Victoria, Australia) atomic absorption spectrophotometer equipped with a background correction (D2 lamp). The samples were prepared according to the procedure described in Manuals of Food Quality Control (18).

\section{Preparation of ethanolic extracts}

Cookies were ground in a laboratory blender (Waring, Torrington, CT, USA) to obtain coarse powder which passed through an $800-\mu \mathrm{m}$ sieve. Cookie powder $(5 \mathrm{~g}$ ) was mixed with $50 \mathrm{~mL}$ of $80 \%$ ethanol. Extraction was carried out by shaking the mixture at ambient temperature $\left((23 \pm 1){ }^{\circ} \mathrm{C}\right)$ for $1 \mathrm{~h}$. After 1-hour shaking, the suspension was left overnight at ambient temperature. The procedure was repeated twice with $50 \mathrm{~mL}$ of solvent, and combined extracts were dried using a vacuum evaporator (Büchi, Flawil, Switzerland). The yield was calculated based on the wet mass of the samples. The dried extract was redissolved in $80 \%$ ethanol to $10 \mathrm{~mL}$ volume and used for further investigation of antioxidant activity.

\section{Total phenolic content}

Total phenolic content of gluten-free rice and buckwheat cookie extracts was determined spectrophotomet- 
rically using Folin-Ciocalteu reagent (19). Gallic acid was used as a standard and results were expressed in $\mu \mathrm{g}$ of gallic acid equivalents (GAE) per $g$ of sample on dry mass basis. The extract $(0.1 \mathrm{~mL})$ was diluted with pure water (7.9 mL, Millipore Elix $10 \mathrm{UV}$ water purification system). Folin-Ciocalteu reagent $(0.5 \mathrm{~mL})$ and sodium carbonate solution $(1.5 \mathrm{~mL} ; \gamma=200 \mathrm{~g} / \mathrm{L})$ were added, and the reaction mixture was mixed thoroughly. The mixture was allowed to stand for $120 \mathrm{~min}$ with intermittent shaking, and the absorbance was measured at $750 \mathrm{~nm}$ (6405 UV/VIS, Jenway, Stone, Staffordshire, UK).

\section{Antioxidant activity measured by $\beta$-carotene bleaching method}

Oxidative loss of $\beta$-carotene in a $\beta$-carotene/linoleic acid emulsion was used to assess the antioxidant activity of the examined extracts (20). $\beta$-Carotene ( $2 \mathrm{mg}$ ) was dissolved in $10 \mathrm{~mL}$ of chloroform and $1 \mathrm{~mL}$ of $\beta$-carotene solution was mixed with $20 \mathrm{mg}$ of purified linoleic acid and $200 \mathrm{mg}$ of Tween 40 in a round-bottom flask. Chloroform was removed by purging with nitrogen. Pure water (50 $\mathrm{mL}$ ) was added into the $\beta$-carotene/linoleic acid emulsion and mixed using a vortex mixer V1 plus (BOECO, Hamburg, Germany). Cookie extracts $(0.2 \mathrm{~mL})$ at various concentrations $(10.0-60.0 \mathrm{mg} / \mathrm{mL})$ and aliquots $(5 \mathrm{~mL})$ of the $\beta$-carotene/linoleic acid emulsion were placed in capped culture tubes and mixed thoroughly. The tubes were immediately placed in a water bath and incubated at $50{ }^{\circ} \mathrm{C}$. Oxidation of $\beta$-carotene/linoleic acid emulsion was monitored spectrophotometrically by measuring the absorbance at $470 \mathrm{~nm}$ after $120 \mathrm{~min}$ (6405 UV/VIS, Jenway). A control was prepared using $0.2 \mathrm{~mL}$ of $80 \%$ ethanol instead of the extract.

Degradation rate (DR) of the extracts was calculated according to the first order kinetics using the following equation (21):

$$
\mathrm{DR}=\ln \left(A_{0} / A\right) \cdot 1 / t
$$

where $A_{0}$ is the initial absorbance $(470 \mathrm{~nm})$ at time zero, $A$ is the absorbance $(470 \mathrm{~nm})$ at time $120 \mathrm{~min}$ and $t$ is time (min).

The antioxidant activity (AA) was expressed as inhibition (in \%) relative to the control using the following equation:

$$
\mathrm{AA}=\left(\frac{\mathrm{DR}(\text { control })-\mathrm{DR}(\text { sample })}{\mathrm{DR}(\text { control })}\right) \cdot 100
$$

The $\mathrm{IC}_{50}$ value $(\mathrm{mg} / \mathrm{mL})$ was defined as the concentration of the extract at which the antioxidant activity was 50 $\%$ under the experimental conditions.

\section{Reducing power}

Reducing power of the cookie extracts was measured according to the method of Oyaizu (22). Various concentrations $(15.0-60.00 \mathrm{mg} / \mathrm{mL})$ of the extracts $(0.5 \mathrm{~mL})$ were mixed with $2.5 \mathrm{~mL}$ of phosphate buffer $(0.2 \mathrm{M}, \mathrm{pH}=6.6)$ and $2.5 \mathrm{~mL}$ of potassium ferricyanide $(1 \%)$. The mixtures were incubated at $50{ }^{\circ} \mathrm{C}$ for $20 \mathrm{~min}$, and after that trichloroacetic acid $(10 \%, 2.5 \mathrm{~mL})$ was added. The mixtures were centrifuged at $650 \times g$ for $10 \mathrm{~min}$ (LC-320, Tehtnica,
Železniki, Slovenia). The supernatant $(2.5 \mathrm{~mL})$ was mixed with $2.5 \mathrm{~mL}$ of pure water and $0.5 \mathrm{~mL}$ of ferric chloride and the absorbance was measured at $700 \mathrm{~nm}$ with spectrophotometer (6405 UV/VIS, Jenway). Higher absorbance of the reaction mixture indicates greater reducing power. The $\mathrm{IC}_{50}$ value $(\mathrm{mg} / \mathrm{mL})$ was defined as the concentration of the extract that causes a decrease in the absorbance of reaction mixture up to 0.5 .

\section{$D P P H$ radical scavenging activity}

Effect of the examined extracts on the content of 1,1-diphenyl-2-picrylhydrazyl radicals (DPPH•) was estimated according to the modified method of Hatano et al. (23). The concentration of the $\mathrm{DPPH}^{\bullet}$ solution used in the assay was $90 \mu \mathrm{M}$, i.e. $22.5 \mathrm{~mL}$ of $0.4 \mathrm{mM} \mathrm{DPPH}^{\bullet}$ solution (0.01577 $\mathrm{g}$ of $\mathrm{DPPH}^{\bullet}$ in $100 \mathrm{~mL}$ of methanol) were diluted with $95 \%$ methanol to $100 \mathrm{~mL}$. An aliquot $(1.0 \mathrm{~mL})$ of the $\mathrm{DPPH}^{\bullet}$ solution $(90 \mu \mathrm{M})$ was diluted in $2.9 \mathrm{~mL}$ of methanol, and $0.1 \mathrm{~mL}$ of the extracts at various concentrations (15.0-60.00 mg/mL) was added. The mixture was shaken vigorously and left to set for $60 \mathrm{~min}$ in the dark, then the absorbance was measured at $517 \mathrm{~nm}$ (6405 UV/VIS, Jenway) against the blank (mixture without the extract).

The $\mathrm{IC}_{50}$ value $(\mathrm{mg} / \mathrm{mL})$ was defined as the concentration of an antioxidant extract which was required to quench $50 \%$ of the initial amount of $\mathrm{DPPH}^{*}$ under the experimental conditions given.

\section{$\mathrm{Fe}^{2+}$ chelating activity}

$\mathrm{Fe}^{2+}$ chelating activity was measured according to the method of Decker and Welch (24). Aliquots of $1 \mathrm{~mL}$ of different concentrations of the extracts $(5.0-60.00 \mathrm{mg} / \mathrm{mL})$ were mixed with $3.7 \mathrm{~mL}$ of pure water. The mixture was left to react with ferrous sulphate heptahydrate $(2 \mathrm{mM}$, $0.1 \mathrm{~mL}$ ) and ferrozine ( $5 \mathrm{mM}, 0.2 \mathrm{~mL}$ ) for $10 \mathrm{~min}$ at ambient temperature $\left((23 \pm 1){ }^{\circ} \mathrm{C}\right)$, and then the absorbance was measured at $562 \mathrm{~nm}$ (6405 UV/VIS, Jenway). A lower absorbance indicates a higher chelating power. Chelating activity (CA) was calculated according to the following equation:

$$
\mathrm{CA}=\left(1-\frac{A_{526 \mathrm{~nm}}(\text { sample })}{A_{526 \mathrm{~nm}}(\text { control })}\right) \cdot 100
$$

The $\mathrm{IC}_{50}$ value $(\mathrm{mg} / \mathrm{mL})$ was defined as the concentration of an antioxidant extract which chelates $50 \%$ of the present $\mathrm{Fe}^{2+}$ under the experimental conditions.

\section{HPLC determination of rutin}

A mass of $5 \mathrm{~g}$ of cookie powder was extracted with 20 $\mathrm{mL}$ of $80 \%$ boiling methanol for $10 \mathrm{~min}$, ultrasonicated for $10 \mathrm{~min}$ and filtered through regenerated cellulose membrane filters $(0.45 \mu \mathrm{m}$ pore size; Agilent Technologies, Santa Clara, CA, USA) before injection into the HPLC system.

HPLC analysis was performed using a liquid chromatograph (Agilent 1200 series), equipped with a diode array detector (DAD), on an Agilent Eclipse XDB-C18, 1.8 $\mathrm{mm}, 4.6 \mathrm{~mm} \times 50 \mathrm{~mm}$ column, at a flow rate of $1 \mathrm{~mL} / \mathrm{min}$. A single rapid resolution HPLC method reported by Mišan et al. (25) was used. The solvent linear gradient 
mode was performed by varying the proportion of solvent $\mathrm{A}$ (methanol) to solvent $\mathrm{B}(1 \mathrm{~mL}$ of formic acid in 100 $\mathrm{mL}$ of water) as follows: initial $10 \% \mathrm{~A}$, then $0-10 \mathrm{~min} 10$ $25 \%$ A, 10-20 min 25-60\% A, and 20-30 min 60-70\% A. The run time and post-run time were 45 and $10 \mathrm{~min}$, respectively. The column was operated at $30^{\circ} \mathrm{C}$. The injected volume of samples and standards was $5 \mu \mathrm{L}$ and it was done automatically, using autosampler. The spectra were acquired in the range of $210-400 \mathrm{~nm}$ and chromatograms plotted at 280, 330 and $350 \mathrm{~nm}$ with reference wavelength set at 550/100 nm. Rutin was identified by matching its retention time and spectral characteristics against rutin standard. The external standard method was used for quantification.

Stock solution of rutin was prepared in the concentration of $1 \mathrm{mg} / \mathrm{mL}$ in methanol. The solution was properly diluted with $1 \%$ formic acid to obtain a series of dilutions in the range of $0.005-34 \mu \mathrm{g} / \mathrm{mL}$ in the mobile phase for external standard calibration.

\section{Sensory evaluation}

Sensory evaluation was conducted $24 \mathrm{~h}$ after baking by eight experienced and trained panellists ( 7 females and 1 male, at the age of 30 to 43). Prior to sensory analysis, sensory profile of gluten-free cookies was established by a multidimensional approach. The established sensory profile included 10 descriptors with their definitions and evaluation techniques (26). To express the intensity of each perceived descriptor, the intensity scale was applied: from 0 , i.e. the absence of perception to 5 , i.e. strong perception/maximal intensity $(27,28)$. The samples were evaluated on three separate occasions. Drinking water was provided for palate cleansing after each sample.

\section{Statistical analysis}

Results were expressed as the mean values of three replications \pm standard deviation. ANOVA and Fisher's multiple range tests were used, and $p<0.05$ were regarded as significant. Principal component analysis (PCA) was carried out to investigate the within-set data profile and to study the correlation between the data. All analyses were made using the XLSTAT software v. 2012.2.02 (Addinsoft, New York, NY, USA).

\section{Results and Discussion}

\section{Proximate composition of cookies}

The main ingredients in gluten-free rice and buckwheat cookie formulation were rice and light buckwheat flour whose mineral and phenolic content and antioxidant activities are presented in Table 1.

The produced gluten-free rice and buckwheat cookies had significantly higher $(\mathrm{p}<0.05)$ protein content in comparison with rice cookies (Table 2). This finding is due to higher protein content of light buckwheat flour (29) compared to rice flour (9). Dietary fibre content of the investigated cookies was found to be significantly different $(p<0.05)$ in the descending order: cookies with $30 \%$ light buckwheat flour>cookies with $20 \%$ light buckwheat flour $>$ cookies with $10 \%$ light buckwheat flour $>$ control cookies. Similar increase in total dietary fibre content was noticed in light and wholegrain buckwheat crackers when they were compared to their wheat counterparts, which corresponded with higher content of dietary fibres in buckwheat flour (30). The increased total dietary fibre content in gluten-free rice and buckwheat cookies contributed to their overall functional properties for the consumption of both adults and children. Namely, children older than two are recommended to consume a minimal amount of dietary fibre equivalent to their age plus $5 \mathrm{~g}$ per day (31). Regarding the highest content of total dietary fibres in cookies containing $30 \%$ light buckwheat flour $((2.94 \pm 0.04) \%)$ (Table 2$)$, it can be concluded that 100 $\mathrm{g}$ of these cookies can satisfy $42 \%$ of a daily dietary fibre intake for 2-year-old children or a lower percentage depending on the age. Therefore, they cannot be considered as high-dietary fibre cookies whose normal consumption

Table 1. Mineral and phenolic content and antioxidant activities of rice flour and light buckwheat flour

\begin{tabular}{|c|c|c|}
\hline Parameter & Rice flour & Light buckwheat flour \\
\hline$w(\mathrm{Mg}) /(\mathrm{mg} / \mathrm{kg})^{*}$ & $(376 \pm 14.1)^{\mathrm{a}}$ & $(1149 \pm 23.6)^{\mathrm{b}}$ \\
\hline$w(\mathrm{~K}) /(\mathrm{mg} / \mathrm{kg})^{*}$ & $(790 \pm 4.1)^{\mathrm{a}}$ & $(2442 \pm 24.2)^{\mathrm{b}}$ \\
\hline$w(\mathrm{Zn}) /(\mathrm{mg} / \mathrm{kg})^{*}$ & $(7.2 \pm 0.8)^{\mathrm{a}}$ & $(13.10 \pm 0.02)^{b}$ \\
\hline$w(\mathrm{Fe}) /(\mathrm{mg} / \mathrm{kg})^{*}$ & $(5.0 \pm 0.5)^{\mathrm{a}}$ & $(11.2 \pm 0.2)^{\mathrm{b}}$ \\
\hline$w(\mathrm{Mn}) /(\mathrm{mg} / \mathrm{kg})^{*}$ & $(6.4 \pm 0.3)^{\mathrm{a}}$ & $(8.1 \pm 0.1)^{b}$ \\
\hline$w(\mathrm{Cu}) /(\mathrm{mg} / \mathrm{kg})^{*}$ & $(1.53 \pm 0.03)^{\mathrm{a}}$ & $(5.1 \pm 0.1)^{\mathrm{b}}$ \\
\hline$w($ total phenolics $) /(\mu \mathrm{g} \text { of GAE per } \mathrm{g})^{*}$ & $(108 \pm 8.1)^{\mathrm{a}}$ & $(2235 \pm 80.7)^{\mathrm{b}}$ \\
\hline$w($ rutin $) /(\mu \mathrm{g} / \mathrm{g})^{*}$ & n.d. & $(128.0 \pm 3.5)$ \\
\hline Antioxidant activity, $\mathrm{IC}_{50} /(\mathrm{mg} / \mathrm{mL})$ & $(13.1 \pm 0.2)^{\mathrm{b}}$ & $(8.4 \pm 0.1)^{\mathrm{a}}$ \\
\hline Reducing activity, $\mathrm{IC}_{50} /(\mathrm{mg} / \mathrm{mL})$ & $(12.9 \pm 0.7)^{\mathrm{b}}$ & $(4.3 \pm 0.1)^{\mathrm{a}}$ \\
\hline $\mathrm{DPPH}^{\bullet}$ scavenging activity, $\mathrm{IC}_{50} /(\mathrm{mg} / \mathrm{mL})$ & $(30.6 \pm 0.4)^{\mathrm{b}}$ & $(1.61 \pm 0.06)^{\mathrm{a}}$ \\
\hline $\mathrm{Fe}^{2+}$ chelating activity, $\mathrm{IC}_{50} /(\mathrm{mg} / \mathrm{mL})$ & $(32.6 \pm 1.9)^{b}$ & $(1.83 \pm 0.03)^{\mathrm{a}}$ \\
\hline
\end{tabular}

* Results are presented on dry mass basis. Values are means of three determinations \pm standard deviation. Values in the same column with the same letter in superscript are not statistically different $(\mathrm{p}<0.05)$.

GAE=gallic acid equivalents 
Table 2. Proximate composition of cookies

\begin{tabular}{lcccc}
\hline$w /(\mathrm{g} / 100 \mathrm{~g})^{*}$ & Control & Sample 1 & Sample 2 & Sample 3 \\
\hline Protein & $(4.4 \pm 0.1)^{\mathrm{a}}$ & $(4.48 \pm 0.02)^{\mathrm{ab}}$ & $(4.60 \pm 0.06)^{\mathrm{b}}$ & $(4.9 \pm 0.1)^{\mathrm{c}}$ \\
Fat & $(19.60 \pm 0.05)^{\mathrm{a}}$ & $(19.60 \pm 0.05)^{\mathrm{a}}$ & $(19.80 \pm 0.24)^{\mathrm{a}}$ & $(19.9 \pm 0.3)^{\mathrm{a}}$ \\
Starch & $(53.2 \pm 0.5)^{\mathrm{a}}$ & $(52.6 \pm 0.7)^{\mathrm{a}}$ & $(52.3 \pm 0.1)^{\mathrm{a}}$ & $(52.30 \pm 0.04)^{\mathrm{a}}$ \\
Reducing sugars & $(15.3 \pm 0.1)^{\mathrm{c}}$ & $(15.10 \pm 0.09)^{\mathrm{ab}}$ & $(15.20 \pm 0.05)^{\mathrm{b}}$ & $(15.00 \pm 0.03)^{\mathrm{a}}$ \\
Ash & $(2.32 \pm 0.02)^{\mathrm{a}}$ & $(2.41 \pm 0.02)^{\mathrm{b}}$ & $(2.41 \pm 0.02)^{\mathrm{b}}$ & $(2.46 \pm 0.01)^{\mathrm{c}}$ \\
Total dietary fibre & $(1.93 \pm 0.03)^{\mathrm{a}}$ & $(2.26 \pm 0.09)^{\mathrm{b}}$ & $(2.55 \pm 0.05)^{\mathrm{c}}$ & $(2.94 \pm 0.04)^{\mathrm{d}}$ \\
\hline
\end{tabular}

*Results are presented on dry mass basis. Values are means of three determinations \pm standard deviation.

Values in the same row with the same letter in superscript are not statistically different $(\mathrm{p}<0.05)$.

Control=rice flour cookies, sample 1=rice flour cookies containing $10 \%$ light buckwheat flour, sample 2=rice flour cookies containing

$20 \%$ light buckwheat flour, sample 3=rice flour cookies containing $30 \%$ light buckwheat flour

could cause harmful effects on children. The other parameters of proximate composition of the investigated cookies were not significantly different.

Since the main ingredients in cookie formulation were rice flour and light buckwheat flour, both known as gluten-free ingredients, the produced cookies were considered to be gluten-free although the presence of gluten needs to be controlled before placing the product on the market. In the case of gluten-free products, their gluten content should be less than $20 \mathrm{mg} / \mathrm{kg}$ according to the Commission Regulation (EC) No 41/2009 of 20 January 2009 concerning the composition and labelling of foodstuffs suitable for people intolerant to gluten (32). This requirement could be satisfied only by purchasing the certified gluten-free ingredients, and applying the strict standards in the production process to avoid cross-contamination.

\section{Mineral content of cookies}

The addition of light buckwheat flour to control gluten-free cookie formulation contributed to the significant increase $(\mathrm{p}<0.05)$ in their mineral content, especially magnesium, potassium, iron and copper (Table 3) due to their significantly higher $(\mathrm{p}<0.05)$ amounts in light buckwheat flour compared to rice flour (Table 1). This finding is in agreement with previously obtained data published by Alvarez-Jubete et al. (2) and Peterson et al. (33). It is assumed that the consummation of gluten-free rice and buckwheat cookies with the improved mineral profile can contribute to the reduction of mineral deficiency in gluten-free diet.
Similar positive correlation between macroelement content and increased amount of buckwheat flour in gluten-free bread was observed by Wronkowska et al. (4). Furthermore, the addition of buckwheat flour significantly increased potassium, magnesium and phosphorus contents of tarhana made with wheat flour (34).

\section{Total phenolic and rutin content}

Due to higher total phenolic content of light buckwheat flour than of rice flour (Table 1), as it was previously determined by Sakač et al. (9), a significant increase $(p<0.05)$ in total phenolic content of gluten-free rice and buckwheat cookies was found in comparison with the rice ones (Table 4). The fortification of gluten-free products using pseudocereals has been reported by Alvarez-Jubete et al. (3), while buckwheat was investigated as a component for gluten-free bread $(9,35)$ and cookies $(8)$.

Rutin, well known as a potent antioxidant (36), dominates in light buckwheat flour (37), but is not present in rice flour (Table 1), which contains ferulic and $p$-coumaric acids as the main polyphenols (38). Therefore, incorporation of light buckwheat flour in gluten-free cookie formulation resulted in an increased concentration of rutin in the following order: cookies with $30 \%$ light buckwheat flour $>$ cookies with $20 \%$ light buckwheat flour>cookies with $10 \%$ light buckwheat flour (Table 3).

Although official dietary intake of polyphenols and rutin has not yet been established, the total dietary intake of polyphenols was recommended to be $1 \mathrm{~g}$ per day (39) or about $1.2 \mathrm{~g}$ per day $(40 \%$ of flavonoids, $60 \%$ of pheno-

Table 3. Mineral content in rice cookies and gluten-free rice and buckwheat cookies

\begin{tabular}{|c|c|c|c|c|c|c|}
\hline \multirow{2}{*}{ Cookies } & \multicolumn{6}{|c|}{$w /(\mathrm{mg} / \mathrm{kg})^{*}$} \\
\hline & $\mathrm{Mg}$ & K & $\mathrm{Zn}$ & $\mathrm{Fe}$ & $\mathrm{Mn}$ & $\mathrm{Cu}$ \\
\hline Control & $(382 \pm 0.3)^{\mathrm{a}}$ & $(823 \pm 1.5)^{a}$ & $(7.83 \pm 0.02)^{a}$ & $(15.3 \pm 0.2)^{a}$ & $(4.8 \pm 0.4)^{\mathrm{a}}$ & $(1.6 \pm 0.1)^{\mathrm{a}}$ \\
\hline Sample 1 & $(463 \pm 10.7)^{\mathrm{b}}$ & $(884 \pm 5.2)^{b}$ & $(8.1 \pm 0.1)^{\mathrm{ab}}$ & $(16.2 \pm 0.3)^{\mathrm{b}}$ & $(4.7 \pm 0.1)^{\mathrm{a}}$ & $(1.64 \pm 0.07)^{\mathrm{a}}$ \\
\hline Sample 2 & $(473 \pm 36.7)^{b}$ & $(961 \pm 1.9)^{c}$ & $(8.02 \pm 0.07)^{\mathrm{ab}}$ & $(17.5 \pm 0.1)^{c}$ & $(4.48 \pm 0.03)^{\mathrm{a}}$ & $(1.81 \pm 0.05)^{b}$ \\
\hline Sample 3 & $(537 \pm 2.9)^{c}$ & $(1063 \pm 27.4)^{\mathrm{d}}$ & $(8.1 \pm 0.2)^{\mathrm{bc}}$ & $(20.6 \pm 0.8)^{d}$ & $(4.7 \pm 0.1)^{\mathrm{a}}$ & $(1.90 \pm 0.07)^{b}$ \\
\hline
\end{tabular}

* Results are presented on dry mass basis. Values are means of three determinations \pm standard deviation.

Values in the same column with the same letter in superscript are not statistically different $(\mathrm{p}<0.05)$.

Control=rice flour cookies, sample $1=$ rice flour cookies containing $10 \%$ light buckwheat flour, sample $2=$ rice flour cookies containing

$20 \%$ light buckwheat flour, sample $3=$ rice flour cookies containing $30 \%$ light buckwheat flour 
Table 4. Phenolic content and antioxidant activities of rice cookies and gluten-free rice and buckwheat cookies

\begin{tabular}{|c|c|c|c|c|c|c|}
\hline \multirow[b]{2}{*}{ Extracts } & \multirow{2}{*}{$\frac{w \text { (total phenolics) }}{\mu \mathrm{g} \text { of GAE per } \mathrm{g}^{*}}$} & \multirow{2}{*}{$\frac{w(\text { rutin })}{\mu \mathrm{g} / \mathrm{g}^{*}}$} & \multicolumn{4}{|c|}{$\mathrm{IC}_{50} /(\mathrm{mg} / \mathrm{mL})$} \\
\hline & & & $\begin{array}{l}\text { Antioxidant } \\
\text { activity }\end{array}$ & $\begin{array}{l}\text { Reducing } \\
\text { activity }\end{array}$ & $\begin{array}{c}\mathrm{DPPH}^{*} \text { scavenging } \\
\text { activity }\end{array}$ & $\begin{array}{c}\mathrm{Fe}^{2+} \text { chelating } \\
\text { activity }\end{array}$ \\
\hline Control & $(955 \pm 46.2)^{\mathrm{a}}$ & n.d. & $(25.0 \pm 0.2)^{\mathrm{a}}$ & $(37.7 \pm 1.0)^{\mathrm{a}}$ & $(23.2 \pm 0.7)^{\mathrm{a}}$ & $(17.6 \pm 0.6)^{\mathrm{a}}$ \\
\hline Sample 1 & $(1038 \pm 43.9)^{b}$ & $(25.1 \pm 0.5)^{\mathrm{a}}$ & $(21.9 \pm 2.6)^{b}$ & $(32.3 \pm 0.6)^{b}$ & $(22.9 \pm 1.4)^{\mathrm{a}}$ & $(4.8 \pm 0.7)^{\mathrm{b}}$ \\
\hline Sample 2 & $(1248 \pm 13.7)^{\mathrm{c}}$ & $(33.3 \pm 0.2)^{\mathrm{b}}$ & $(18.7 \pm 1.7)^{\mathrm{c}}$ & $(31.3 \pm 0.8)^{\mathrm{b}}$ & $(16.8 \pm 0.8)^{b}$ & $(4.8 \pm 1.0)^{\mathrm{b}}$ \\
\hline Sample 3 & $(1349 \pm 16.9)^{\mathrm{d}}$ & $(40.1 \pm 0.6)^{\mathrm{c}}$ & $(11.4 \pm 1.0)^{\mathrm{d}}$ & $(29.0 \pm 1.2)^{c}$ & $(14.7 \pm 0.9)^{\mathrm{c}}$ & $(4.6 \pm 0.5)^{\mathrm{b}}$ \\
\hline
\end{tabular}

*Results are presented on dry mass basis. Values are means of three determinations \pm standard deviation.

Values of the same column with the same letter in superscript are not statistically different $(\mathrm{p}<0.05)$.

Control=rice flour cookies, sample $1=$ rice flour cookies containing $10 \%$ light buckwheat flour, sample $2=$ rice flour cookies containing

$20 \%$ light buckwheat flour, sample 3=rice flour cookies containing $30 \%$ light buckwheat flour

lic acids) (40), while the intake of 10-25 mg per day of rutin for adults and 5-10 mg per day for children are considered safe (41). In this view, $100 \mathrm{~g}$ of cookies with $30 \%$ light buckwheat flour, which contain the highest amount of polyphenols and rutin among the examined cookies (Table 4), could contribute to approx. $12 \%$ of daily polyphenol intake and less than $8 \%$ of daily rutin intake for children. These findings suggest that problems connected with the excessive polyphenol and rutin intake should not be expected at moderate consumption of gluten-free rice and buckwheat cookies.

\section{Antioxidant properties}

The antioxidant activity of buckwheat flour is superior to that of rice flour (Table 1), due to its higher total phenolic content (9), especially rutin (37). Therefore, the incorporation of light buckwheat flour in gluten-free cookie formulation resulted in increased antioxidant activity of the enriched gluten-free cookies (Table 4), expressed as $\mathrm{IC}_{50}$.

The $\mathrm{IC}_{50}$ values of antioxidant activity among all investigated buckwheat-enriched cookie extracts differed significantly $(\mathrm{p}<0.05)$ from the $\mathrm{IC}_{50}$ value of control cookies. Antioxidant activity negatively correlated with the total phenolic content $(\mathrm{R}=-0.951)$, suggesting that phenolic compounds in the produced cookies mainly contributed to their overall antioxidant properties. However, thermal processing of cereals, such as baking, also resulted in the formation of substances with antioxidant properties, namely Maillard reaction products (42) that contribute to the overall antioxidant activity of bakery products. Sensoy et al. (43) stated that the accumulation of these products in bread crust was responsible for significant increase in its antioxidant activity.

Significant differences $(p<0.05)$ in reducing activity were found between the samples, except between the samples containing 10 and $20 \%$ light buckwheat flour (Table 4). The enrichment of cookie formulation with $30 \%$ light buckwheat flour resulted in superior reducing activity due to the fact that buckwheat presents one of the greatest sources of antioxidants amongst cereals and pseudocereals (37). Alvarez-Jubete et al. (11) reported that buckwheat seeds and sprouts as well as buckwheat bread were rich in reducing agents.

The buckwheat-enriched cookie extracts exhibited scavenging activity against $\mathrm{DPPH}^{\bullet}$ in the descending or- der: cookies containing $30 \%$ buckwheat flour $>20 \%$ buckwheat flour $>10 \%$ buckwheat flour control cookies (Table 4). The increased amount of light buckwheat flour in the formulation of cookies positively correlated with the scavenging activity against $\mathrm{DPPH}^{\bullet}$ due to the approx. 20 times higher scavenging activity against $\mathrm{DPPH}^{\bullet}$ of light buckwheat flour extract than of rice flour extract (Table 1). The buckwheat flour capacity to scavenge $\mathrm{DPPH}^{\bullet}$ is mainly attributed to the presence of rutin, which was confirmed as a potent $\mathrm{DPPH}^{\bullet}$ scavenger (14).

The addition of $10-30 \%$ of light buckwheat flour to the gluten-free cookie formulation improved the $\mathrm{Fe}^{2+}$ chelating activity but without significant differences $(p<0.05)$ among different samples (Table 4). It is assumed that the determined increase in $\mathrm{Fe}^{2+}$ chelating activity of cookies enriched with light buckwheat flour could be explained by the chelating properties of rutin, which was specified as metal chelator and/or radical scavenger in the Fenton reaction (36).

\section{Sensory properties}

Most of the sensory properties were not significantly influenced by the addition of light buckwheat flour compared to the control sample (Table 5). However, the substitution with $20 \%$ of light buckwheat flour in control gluten-free cookie formulation resulted in significantly distinct intensity $(p<0.05)$ of colour and odour. These results are in agreement with previously published findings of Luthar (44), who found that the presence of aromatic compounds in buckwheat flour improved the pleasant odour and taste compared to the bland and neutral rice flour (45). More intensive colour was found in the samples with 20 and $30 \%$ of substituted flour than in the other two samples, due to the differences in amino acid profile (46) and the content of reducing sugars between buckwheat and rice flour, which further caused the differences in nonenzymatic browning reaction during baking (47).

Regarding textural properties, supplementation of light buckwheat flour negatively influenced the hardness of the cookies when compared to the control sample (Table 5). In a previous study (48) which focused on instrumental texture and dimensional measurements of these cookies, partial replacement of rice flour with buckwheat flour led to a decrease in cookie hardness, fracturability and percentage of contraction, and an increase in the per- 
Table 5. Sensory scores of cookies

\begin{tabular}{lllll}
\hline Property & Control & Sample 1 & Sample 2 & Sample 3 \\
\hline Colour & $(3.1 \pm 0.5)^{\mathrm{a}}$ & $(3.3 \pm 0.5)^{\mathrm{ab}}$ & $(3.9 \pm 0.7)^{\mathrm{c}}$ & $(3.7 \pm 0.8)^{\mathrm{bc}}$ \\
Odour & $(3.1 \pm 0.7)^{\mathrm{a}}$ & $(3.2 \pm 0.4)^{\mathrm{a}}$ & $(3.7 \pm 0.6)^{\mathrm{b}}$ & $(3.2 \pm 0.6)^{\mathrm{ab}}$ \\
Fatness & $(3.2 \pm 0.8)^{\mathrm{a}}$ & $(3.3 \pm 0.5)^{\mathrm{a}}$ & $(3.5 \pm 0.5)^{\mathrm{a}}$ & $(3.6 \pm 0.8)^{\mathrm{a}}$ \\
Hardness & $(4.1 \pm 0.5)^{\mathrm{b}}$ & $(3.2 \pm 0.8)^{\mathrm{a}}$ & $(3.3 \pm 0.6)^{\mathrm{a}}$ & $(3.4 \pm 0.7)^{\mathrm{a}}$ \\
Crumbliness & $(1.7 \pm 0.8)^{\mathrm{a}}$ & $(1.8 \pm 0.9)^{\mathrm{ab}}$ & $(2.3 \pm 0.5)^{\mathrm{b}}$ & $(2.1 \pm 0.8)^{\mathrm{ab}}$ \\
Sharpness & $(3.2 \pm 0.4)^{\mathrm{a}}$ & $(2.8 \pm 0.8)^{\mathrm{a}}$ & $(2.8 \pm 0.8)^{\mathrm{a}}$ & $(2.8 \pm 0.7)^{\mathrm{a}}$ \\
Fracturability & $(3.2 \pm 1.1)^{\mathrm{a}}$ & $(3.7 \pm 0.9)^{\mathrm{a}}$ & $(3.8 \pm 0.9)^{\mathrm{a}}$ & $(3.5 \pm 0.8)^{\mathrm{a}}$ \\
Adhesiveness & $(2.6 \pm 0.9)^{\mathrm{a}}$ & $(2.3 \pm 0.9)^{\mathrm{a}}$ & $(2.1 \pm 0.9)^{\mathrm{a}}$ & $(2.2 \pm 0.6)^{\mathrm{a}}$ \\
Particle size/shape & $(3.2 \pm 0.6)^{\mathrm{a}}$ & $(3.4 \pm 0.7)^{\mathrm{a}}$ & $(3.5 \pm 0.7)^{\mathrm{a}}$ & $(3.7 \pm 0.8)^{\mathrm{a}}$ \\
Taste & $(3.1 \pm 0.6)^{\mathrm{a}}$ & $(3.4 \pm 0.7)^{\mathrm{b}}$ & $(3.5 \pm 0.5)^{\mathrm{b}}$ & $(3.6 \pm 0.5)^{\mathrm{b}}$ \\
\hline
\end{tabular}

Scores are mean values \pm standard deviation. Values in the same row with the same letter in superscript are not statistically different $(\mathrm{p}<0.05)$

Control=rice flour cookies, sample 1=rice flour cookies containing $10 \%$ light buckwheat flour, sample 2=rice flour cookies containing $20 \%$ light buckwheat flour, sample 3=rice flour cookies containing $30 \%$ light buckwheat flour

centage of spread and eccentricity. Thus, lower scores for hardness of gluten-free rice and buckwheat cookies in our experiment could be attributed to the differences in rheological properties between the rice dough and the dough made from rice flour and light buckwheat flour. Rice dough was stronger (higher elastic modulus and lower maximum creep compliance) and more elastic (lower tan $\delta$, higher recovery) than the dough made with rice flour and light buckwheat flour mixtures (48).

Moreover, comparing the enriched cookies with the control, which was set as the reference/average value, cookies with $20 \%$ light buckwheat flour had better sensory quality with higher scores or values closer to the average of the properties considered as positive for this type of product. On the contrary, as the crumbliness and adhesiveness are considered to be less positive properties, cookies with $20 \%$ light buckwheat flour showed acceptable sensory quality due to lower than average scores (Table 5).

Generally, the addition of light buckwheat flour to the gluten-free cookie formulation did not have a negative influence on their sensory quality. In comparison with other investigated samples, the cookies containing $20 \%$ light buckwheat flour were found to have the most acceptable sensory properties. Our findings are in accordance with the previous findings of Torbica et al. (35), who applied a different sensory method of evaluation.

\section{Principal component analysis}

The results of ANOVA revealed clear significant differences among cookies for each determined parameter (Tables 2-5), while the principal component analysis (PCA) gave the insight into the relevant properties which provide a perceptual map of the gluten-free cookies. The data were standardized and submitted to the correlation matrix. The first two dimensions accounted for $90.97 \%$ of the total variance, $78.22 \%$ of which were explained by the first dimension. F2 and F3 components carried out 12.75 and $9.03 \%$ of the total information given by the gluten-free cookie profiles. The factor loadings (correlation coef- ficients between variables and F-factors) are listed in Table 6 . From this table it can be concluded which variables are well linked with an axis based on the squared cosine values (factor loadings). The higher the value of the factor loadings $(\geq 0.5)$, the more important that variable is to the corresponding axis. Therefore, the properties with high positive or negative loadings summarized the meaning of the first three components.

Sensory properties (colour, odour, fatness, crumbliness, fracturability, particle size and taste), chemical components (proteins, fat, ash and total dietary fibre), all minerals except manganese, and total phenolic content and rutin exhibited positive factor loadings for F1, while the remaining properties exhibited negative factor loadings. Consequently, these properties were found in most of the samples at different intensity levels and exhibited differences among the gluten-free cookies, because F1 had the highest eigenvalue (21.903). It should be pointed out that the second dimension of the PCA can be explained only by two sensory properties (odour and fracturability) and manganese.

According to Kallithraka et al. (49) and Bower (50), the samples that are close to each other in PCA score plot possess similar overall properties and samples that are far apart are very different. In Fig. 1 the samples are positioned in different areas except the sample with $10 \%$ light buckwheat flour, due to the difference in their composition. The main parameters characterizing the control sample are: starch, chelating activity, adhesiveness, hardness and sharpness. On the other hand, the PCA of all measurements and sensory evaluation resulted in effective classification of the cookies with 20 and $30 \%$ light buckwheat flour into two groups of samples. The parameters which describe this grouping were primarily odour and fracturability of the cookies with $20 \%$ light buckwheat flour, and iron and protein content of the cookies with 30 $\%$ light buckwheat flour.

Cookies with $10 \%$ light buckwheat flour could not be classified in a separate group because they were not similar to the others (Fig. 1). Neither the sensory evaluation 
Table 6. Principal component (PC) values, factor loadings and eingevalues for each PC

\begin{tabular}{|c|c|c|c|}
\hline \multirow[b]{3}{*}{ Eigenvalues } & \multicolumn{3}{|c|}{ PC } \\
\hline & $\mathrm{F} 1=78.22 \%$ & $\mathrm{~F} 2=12.75 \%$ & F3 $=9.03 \%$ \\
\hline & 21.903 & 3.569 & 2.528 \\
\hline & \multicolumn{3}{|c|}{ Factor loadings } \\
\hline \multicolumn{4}{|l|}{ Sensory properties } \\
\hline Colour & 0.886 & -0.299 & 0.355 \\
\hline Odour & 0.605 & -0.589 & 0.536 \\
\hline Fatness & 0.965 & 0.166 & 0.203 \\
\hline Hardness & -0.781 & 0.459 & 0.424 \\
\hline Crumbliness & 0.812 & -0.273 & 0.516 \\
\hline Sharpness & -0.773 & 0.387 & 0.503 \\
\hline Fracturability & 0.693 & -0.714 & -0.101 \\
\hline Adhesiveness & -0.875 & 0.457 & -0.160 \\
\hline Particle size & 0.969 & 0.235 & -0.075 \\
\hline Taste & 0.993 & -0.092 & -0.076 \\
\hline \multicolumn{4}{|l|}{ Proximate composition } \\
\hline Protein & 0.879 & 0.474 & 0.059 \\
\hline Fat & 0.883 & 0.316 & 0.347 \\
\hline Starch & -0.979 & 0.200 & 0.045 \\
\hline Reducing sugar & -0.784 & -0.307 & 0.539 \\
\hline Ash & 0.952 & 0.076 & -0.296 \\
\hline Total dietary fibre & 0.967 & 0.253 & 0.023 \\
\hline \multicolumn{4}{|l|}{ Mineral content } \\
\hline $\mathrm{Mg}$ & 0.960 & 0.185 & -0.212 \\
\hline K & 0.946 & 0.315 & 0.070 \\
\hline $\mathrm{Zn}$ & 0.876 & -0.144 & -0.461 \\
\hline $\mathrm{Fe}$ & 0.879 & 0.476 & 0.040 \\
\hline $\mathrm{Mn}$ & -0.622 & 0.715 & -0.320 \\
\hline $\mathrm{Cu}$ & 0.896 & 0.306 & 0.320 \\
\hline \multicolumn{4}{|l|}{ Antioxidant properties } \\
\hline Antioxidant activity & -0.908 & -0.418 & -0.015 \\
\hline Reducing activity & -0.980 & -0.012 & 0.198 \\
\hline DPPH & -0.900 & -0.240 & -0.365 \\
\hline Chelating activity & -0.885 & 0.319 & 0.340 \\
\hline Total phenolic content & 0.956 & 0.190 & 0.223 \\
\hline Rutin & 0.990 & -0.065 & -0.129 \\
\hline
\end{tabular}

Bold factor loadings were heavily loaded $(>|0.5|)$

parameters nor minerals, chemical or antioxidant parameters could be correlated to this sample.

In general, it can be concluded that almost all antioxidant and positive sensory properties appeared to be much more effective in describing the gluten-free cookies with 20 and $30 \%$ light buckwheat flour than the other two samples. In Fig. 1 (F1 vs. F2) all mentioned parameters (variables) appeared to be very highly correlated (positively or negatively) with F1 factor. Therefore, the results derived using PCA showed a reasonable agreement with the number of variables relevant in discrimination among the cookies.

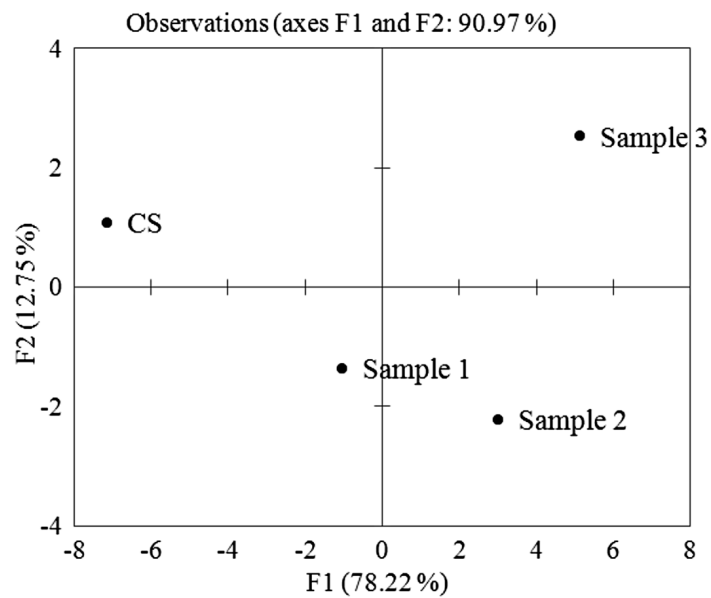

Fig. 1. PCA score plot of the samples: $C S=$ cookies made with rice flour, samples 1, 2 and $3=$ rice flour cookies containing 10, 20 and $30 \%$ of light buckwheat flour, respectively

\section{Conclusions}

Light buckwheat flour was used to enhance mineral content and antioxidant capacity of gluten-free rice and buckwheat cookies compared to the rice cookies used as the control. The substitution of rice flour in gluten-free cookie formulation with 10 to $30 \%$ light buckwheat flour resulted in significantly higher $(\mathrm{p}<0.05)$ mineral content, total phenolic content and rutin content, scavenging activity against $\mathrm{DPPH}^{\bullet}$, antioxidant activity and reducing power than in the control cookies. Comparing all evaluated sensory properties, cookies enriched with $20 \%$ light buckwheat flour expressed the most acceptable sensory properties. The obtained results of PCA showed that almost all antioxidant and positive sensory properties were much more effective in describing cookies containing 20 and $30 \%$ light buckwheat flour than the other two samples. Therefore, the use of light buckwheat flour in gluten-free cookies can be beneficial due to the increased antioxidant activity and mineral content. The confirmation of the mentioned benefit of using light buckwheat flour in the production of gluten-free cookies could be obtained in in vivo experiment, which might be part of our further investigations.

\section{Acknowledgements}

This work was financially supported by the Ministry of Education, Science and Technological Development, Republic of Serbia (Project No. TR-31029).

\section{References}

1. Thompson T, Dennis M, Higgins LA, Lee AR, Sharrett MK. Gluten-free diet survey: are Americans with celiac disease consuming recommended amounts of fibre, iron, calcium and grain foods? J Hum Nutr Diet. 2005;18:163-9. http://dx.doi.org/10.1111/j.1365-277X.2005.00607.x

2. Alvarez-Jubete L, Arendt EK, Gallagher E. Nutritive value and chemical composition of pseudocereals as gluten-free ingredients. Int J Food Sci Nutr. 2009;60S4:240-57. http://dx.doi.org/10.1080/09637480902950597

3. Alvarez-Jubete L, Arendt EK, Gallagher E. Nutritive value of pseudocereals and their increasing use as functional gluten- 
-free ingredients. Trends Food Sci Tech. 2010;21:106-13. http://dx.doi.org/doi:10.1016/j.tifs.2009.10.014

4. Wronkowska M, Zielińska D, Szawara-Nowak D, Troszyńska A, Soral-Śmietana M. Antioxidative and reducing capacity, macroelements content and sensorial properties of buckwheat-enhanced gluten-free bread. Int J Food Sci Tech. 2010; 45:1993-2000. http://dx.doi.org/10.1111/j.1365-2621.2010.02375.x

5. Schoenlechner R, Drausinger J, Ottenschlaeger V, Jurackova $\mathrm{K}$, Berghofer E. Functional properties of gluten-free pasta produced from amaranth, quinoa and buckwheat. Plant Food Hum Nutr. 2010;65:339-49. http://dx.doi.org/10.1007/s11130-010-0194-0

6. Gallagher E, Gormley TR, Arendt KE. Recent advances in the formulation of gluten-free cereal-based products. Trends Food Sci Tech. 2004;15:143-52. http://dx.doi.org/10.1016/j.tifs.2003.09.012

7. Rodrigues FT, Fanaro GB, Duarte RC, Koike AC, Villavicencio ALCH. A sensory evaluation of irradiated cookies made from flaxseed meal. Radiat Phys Chem. 2012;81:1157-9. http://dx.doi.org/10.1016/j.radphyschem.2012.02.001

8. Torbica A, Hadnađev M, Dapčević Hadnađev T. Rice and buckwheat flour characterization and its relation to cookie quality. Food Res Int. 2012;48:277-83. http://dx.doi.org/10.1016/j.foodhyd.2010.03.004

9. Sakač M, Torbica A, Sedej I, Hadnađev M. Influence of breadmaking on antioxidant capacity of gluten free breads based on rice and buckwheat flours. Food Res Int. 2011;44:2806-13. http://dx.doi.org/10.1016/j.foodres.2011.06.026

10. Gujral HS, Rosell CM. Functionality of rice flour modified with a microbial transglutaminase. J Cereal Sci. 2004;39:225-30. http://dx.doi.org/10.1094/CC-82-0425

11. Alvarez-Jubete L, Wijngaard H, Arendt EK, Gallagher E. Polyphenol composition and in vitro antioxidant activity of amaranth, quinoa buckwheat and wheat as affected by sprouting and baking. Food Chem. 2010;119:770-8. http://dx.doi.org/10.1016/j.foodchem.2009.07.032

12. Zieliński H, Michalska A, Amigo-Benavent M, del Castillo D, Piskuła MK. Changes in protein quality and antioxidant properties of buckwheat seeds and groats induced by roasting. J Agric Food Chem. 2009;57:4771-6. http://dx.doi.org/10.1021/jf900313e

13. Oomah BD, Mazza G. Flavonoids and antioxidative activities in buckwheat. J Agric Food Chem. 1996;44:1746-50. http://dx.doi.org/10.1021/jf9508357

14. Jiang P, Burczynski F, Campbell C, Pierce G, Austria JA, Briggs CJ. Rutin and flavonoid in three buckwheat species Fagopyrum esculentum, F. tataricum, and F. homotropicum and their protective effects against lipid peroxidation. Food Res Int. 2007;40:356-64.

http://dx.doi.org/10.1016/j.foodres.2006.10.009

15. Schönlechner R, Linsberger G, Kaczyk L, Berghofer E. Production of gluten-free short dough biscuits from the pseudocereals amaranth, quinoa and buckwheat with common bean. Ernährung/Nutrition. 2006;30:101-7.

16. Official Methods of Analysis of the AOAC. 17th ed. Maryland, USA: AOAC International; 2000.

17. International Association for Cereal Science and Technology. ICC Standard No. 123/1. Determination of starch content by hydrochloric acid dissolution. Vienna, Austria: ICC; 1994.

18. Manuals of Food Quality Control. 2. Additives, Contaminants, Techniques. FAO Food and Nutrition Paper. Rome, Italy: FAO; 1980.

19. Singleton VL, Orthofer R, Lamuela-Raventos RM. Analysis of total phenols and other oxidation substrates and antioxidants by means of Folin-Ciocalteu reagent. Method Enzymol. 1999;299:152-78.

http://dx.doi.org/10.1016/S0076-6879(99)99017-1
20. Moure A, Cruz JM, Franco D, Domínguez JM, Sineiro J, Domínguez $\mathrm{H}$, et al. Natural antioxidants from residual sources. Food Chem. 2001;72:145-71. http://dx.doi.org/10.1016/S0308-8146(00)00223-5

21. Al-Saikhan MS, Howard LR, Miller Jr JC. Antioxidant activity and total phenolics in different genotypes of potato (Solanum tuberosum L.). J Food Sci. 1995;60:341-7. http://dx.doi.org/10.1111/j.1365-2621.1995.tb05668.x

22. Oyaizu M. Studies on products of browning reaction - Antioxidant activities of products of browning reaction prepared from glucosamine. Jpn J Nutr. 1986;44:307-15. http://dx.doi.org/10.5264/eiyogakuzashi.44.307

23. Hatano T, Kagawa H, Yasuhara T, Okuda T. Two new flavonoids and other constituents in licorice root: their relative astringency and radical scavenging effects. Chem Pharm Bull. 1988;36:2090-7. http://dx.doi.org/ 10.1248/cpb.36.2090

24. Decker EA, Welch B. Role of ferritin as a lipid oxidation catalyst in muscle food. J Agric Food Chem. 1990;38:674-7. http://dx.doi.org/10.1021/jf00093a019

25. Mišan A, Mimica-Dukić N, Mandić A, Sakač M, Milovanović I, Sedej I. Development of a rapid resolution HPLC method for the separation and determination of 17 phenolic compounds in crude plant extracts. Cent Eur J Chem. 2011;9:13342.

http://dx.doi.org/10.2478/s11532-010-0126-8

26. Jambrec D, Pestorić M, Žigon U. Development and application of descriptors for establishing sensory profile of gluten-free cookies by a multidimensional approach. Food Feed Res. 2012;39:41-9.

27. ISO 11035:1994. Sensory analysis - Identification and selection of descriptors for establishing a sensory profile by a multidimensional approach. Geneva, Switzerland; 1994.

28. ISO 4121:2003. Sensory analysis - Guidelines for the use of quantitative response scales. Geneva, Switzerland; 2003.

29. Sedej I, Mandić A, Sakač M, Mišan A, Tumbas V. Comparison of antioxidant components and activity of buckwheat and wheat flours. Cereal Chem. 2010;87:387-92. http://dx.doi.org/10.1094/CCHEM-02-10-0018

30. Sedej I, Sakač M, Mandić A, Mišan A, Pestorić M, Šimurina $\mathrm{O}$, et al. Quality assessment of gluten-free crackers based on buckwheat flour. LWT-Food Sci Technol. 2011;44:694-9. http://dx.doi.org/10.1016/j.lwt.2010.11.010

31. Williams CL, Bollella M, Wynder EL. A new recommendation for dietary fiber in childhood. Pediatrics. 1995;96:985-8.

32. Commission Regulation (EC) No 41/2009 of 20 January 2009 concerning the composition and labelling of foodstuffs suitable for people intolerant to gluten. Off J EU. 2009;16/3-16/5.

33. Peterson CJ, Johnson VA, Mattern PJ. Evaluation of variation in mineral element concentrations in wheat flour and bran of different cultivars. Cereal Chem. 1983;60:450-5.

34. Bilgiçli N. Effect of buckwheat flour on chemical and functional properties of tarhana. LWT-Food Sci Technol. 2009;42: 514-8. http://dx.doi.org/10.1016/j.lwt.2008.09.006

35. Torbica A, Hadnađev M, Dapčević T. Rheological, textural and sensory properties of gluten-free bread formulations based on rice and buckwheat flour. Food Hydrocolloid. 2010;24:626-32. http://dx.doi.org/10.1016/j.foodhyd.2010.03.004

36. Yang J, Guo J, Yuan J. In vitro antioxidant properties of rutin. LWT-Food Sci Technol. 2008;41:1060-6. http://dx.doi.org/10.1016/j.lwt.2007.06.010

37. Holasova M, Fiedlerova V, Smrcinova H, Orsak M, Lachman L, Vavreinova S. Buckwheat - The source of antioxidant activity in functional foods. Food Res Int. 2002;35:207-11. http://dx.doi.org/10.1016/S0963-9969(01)00185-5 
38. Harukaze A, Murata M, Homma S. Analyses of free and bound phenolics in rice. Food Sci Technol Res. 1999;5:74-9. http://dx.doi.org/10.3136/fstr.5.74

39. Scalbert A, Williamson G. Dietary intake and bioavailability of polyphenols. J Nutr. 2000;130:2073S-85S.

40. Habauzit V, Morand C. Evidence for a protective effect of polyphenols-containing foods on cardiovascular health: an update for clinicians. Ther Adv Chronic Dis. 2012;3:87-106. http://dx.doi.org/10.1177/2040622311430006

41. Acu-Cell Nutrition: Bioflavonoids Rutin-Hesperidin. Available from: URL: http://www.acu-cell.com/bio.html.

42. Lindenmeier $\mathrm{M}$, Hofmann $\mathrm{T}$. Influence of baking conditions and precursor supplementation on the amounts of the antioxidant pronyl-L-lysine in bakery products. J Agric Food Chem. 2004;52:350-4. http://dx.doi.org/10.1021/jf0346657

43. Sensoy I, Rosen RT, Ho CT, Karwe MV. Effect of processing on buckwheat phenolics and antioxidant activity. Food Chem. 2006;99:388-93. http://dx.doi.org/10.1016/j.foodchem.2005.08.007

44. Luthar Z. Polyphenol classification and tannin content of buckwheat seeds (Fagopyrum esculentum Moench). Fagopyrum. 1992;12:36-42.
45. Kadan RS, Bryant RJ, Miller JA. Effects of milling on functional properties of rice flour. J Food Sci. 2008;73:E151-4. http://dx.doi.org/10.1111/j.1750-3841.2008.00720.x

46. Edwardson S. Buckwheat: Pseudocereal and nutraceutical. In: J. Janick, editor. Progress in new crops. Alexandria, VA, USA: ASHS Press; 1996. pp. 195-207.

47. Zucco F, Borsuk Y, Arntfield SD. Physical and nutritional evaluation of wheat cookies supplemented with pulse flours of different particle sizes. LWT-Food Sci Technol. 2011;44: 2070-6. http://dx.doi.org/10.1016/j.lwt.2011.06.007

48. Dapčević Hadnađev T, Torbica A, Hadnađev M. Influence of buckwheat flour and carboxymethyl cellulose on rheological behaviour and baking performance of gluten-free cookie dough. Food Bioprocess Tech. 2013;6:1770-81. http://dx.doi.org/10.1007/s11947-012-0841-6

49. Kallithraka S, Arvanitoyannis IS, Kefalas P, El-Zajouli A, Soufleros E, Psarra E. Instrumental and sensory analysis of Greek wines; implementation of principal component analysis (PCA) for classification according to geographical origin. Food Chem. 2001;73:501-14. http://dx.doi.org/10.1016/S0308-8146(00)00327-7

50. Bower JA. Principal component analysis. In: Statistical methods for food science: introductory procedures for the food Practitioner. Oxford, UK: Wiley-Blackwell Ltd; 2009. p. 45. 